A. Bakurova, O. Yuskiv, D. Shyrokorad, A. Riabenko, E. Tereschenko

\title{
NEURAL NETWORK FORECASTING OF ENERGY CONSUMPTION OF A METALLURGICAL ENTERPRISE
}

\begin{abstract}
The subject of the research is the methods of constructing and training neural networks as a nonlinear modeling apparatus for solving the problem of predicting the energy consumption of metallurgical enterprises. The purpose of this work is to develop a model for forecasting the consumption of the power system of a metallurgical enterprise and its experimental testing on the data available for research of PJSC "Dneprospetsstal". The following tasks have been solved: analysis of the time series of power consumption; building a model with the help of which data on electricity consumption for a historical period is processed; building the most accurate forecast of the actual amount of electricity for the day ahead; assessment of the forecast quality. Methods used: time series analysis, neural network modeling, short-term forecasting of energy consumption in the metallurgical industry. The results obtained: to develop a model for predicting the energy consumption of a metallurgical enterprise based on artificial neural networks, the MATLAB complex with the Neural Network Toolbox was chosen. When conducting experiments, based on the available statistical data of a metallurgical enterprise, a selection of architectures and algorithms for learning neural networks was carried out. The best results were shown by the feedforward and backpropagation network, architecture with nonlinear autoregressive and learning algorithms: Levenberg-Marquard nonlinear optimization, Bayesian Regularization method and conjugate gradient method. Another approach, deep learning, is also considered, namely the neural network with long short-term memory LSTM and the adam learning algorithm. Such a deep neural network allows you to process large amounts of input information in a short time and build dependencies with uninformative input information. The LSTM network turned out to be the most effective among the considered neural networks, for which the indicator of the maximum prediction error had the minimum value. Conclusions: analysis of forecasting results using the developed models showed that the chosen approach with experimentally selected architectures and learning algorithms meets the necessary requirements for forecast accuracy when developing a forecasting model based on artificial neural networks. The use of models will allow automating high-precision operational hourly forecasting of energy consumption in market conditions.
\end{abstract}

Keywords: energy consumption; forecasting; artificial neural network; time series.

\section{Introduction}

Black metallurgy is one of the most energy-intensive industrial sectors. It is characterized by a high level of electricity consumption that is a significant component of energy use. Thus, the share of electricity in the cost of production of large enterprises in the industry varies from $11 \%$ to $16 \%$, and in some cases its share increases to $30 \%$ [1].

The most electricity-intensive are steel production (its share of consumption is $32.3 \%$ ), production of hot $(21.9 \%)$ and cold-rolled products $(12 \%)$, as well as agglomerative production $(14.5 \%)$, blast-furnace based steel production (6.9\%) and coke production (5.2\%) [2].

The maximum specific consumption of electricity that is in electric steel production is $727 \mathrm{kWh} / \mathrm{t}$ of steel. Under this condition the consumption of electricity per ton of steel depends on the power of transformers, the specific electric power of arc furnaces, the use of fuel and oxygen burners, preheating of scrap and out-of-furnace processing.

The power consumption forecast in metallurgy that is necessary for optimal control of loading modes of electric power plants, which includes regulation of active and reactive loads of metallurgical enterprise, minimization of losses from reactive power flows and maintenance of voltage within set limits in electric networks due to strict power quality requirements.

The power consumption forecast in metallurgy that is necessary for optimal control of loading modes of electric power plants, which includes regulation of active and reactive loads of metallurgical enterprise, minimization oflosses from reactive power flows and maintenance of voltage within set limits in electric networks due to strict power quality requirements.

The peculiarities of electricity consumption by ferrous metallurgy enterprises include: a large number of electrical equipment that is used in the implementation of the technological process in each unit; great variety of types and capacities of electricity receivers; relatively weak links between the mutual influence of electricity receivers in the implementation of the technological process; a large number of electrical equipment that participates in ensuring the technological process in each unit and creates a conditionally constant load, also depends on the intensity of the technological process; factors those randomly affect the modes and volume of electricity consumption; a large number of hours of use of maximum electric power; large electrical intensity of the final product types; the possibility of changing the modes of operation and composition of equipment in the unit, product range and other systematically acting factors [3].

Therefore, the problem of forecasting electricity consumption in metallurgical production is one of the important scientific and practical tasks in the power industry today.

Planning is one of the main management functions. The deviation of actual consumption from the declared numbers by more than a certain percentage leads to the purchase of electricity from the balancing market at a higher price, deviation to a lesser value is also being punished by payment for undelivered electricity, which is determined by the difference between declared and actual consumption by the set fee rates.

The complexity of the energy consumption forecast caused by the need to consider many factors that affect 
electricity consumption (the environment temperature; the level light; the day length; day of the week; transitions from winter to summer time and back; the presence of extraordinary events (disasters; mass actions); weather forecasts the state of other factors that affect the change in consumption in accordance to the data obtained from the processing of consumption statistics).

Improving the accuracy of forecasting saves energy resources, determines the efficiency of power supply management and, accordingly, increases the profits of energy companies. The need for accurate forecasting of electricity consumption is conditioned by technological and economic reasons. The total payment for the consumed electricity for the enterprise as a market participant consists of the payment for the actually consumed volume of electricity and the payment for the deviation of the actually consumed volume from the declared (forecasted) one. The higher possibility of the forecast error is, the greater is the deviation of the actual amount of electricity consumed from the declared (forecast) the greater is the additional costs of the enterprise to pay for electricity. Thus, reducing the forecast error will allow the enterprise to reduce the additional fee for electricity consumption caused by inaccurate forecasting.

In large energy-intensive industries, the share of electricity bills in the cost of production can reach tens of percent (for example, in metallurgical production, it is $11 \%-30 \%$ ) [4], and in a market economy, the prime cost of production will determine its competitiveness. Thus, in the conditions of modern energy market for large enterprises and mining industries it is important to create a system of hourly electricity consumption, which minimizes the deviation of power consumption from the declared.

Based on the done forecast, the actual and optimal modes of operation of power systems are calculated, as well as qualitative parameters (reliability, quality of electricity, etc.) are evaluated. Clear forecasting of electricity consumption provides optimal load distribution within the production process.

\section{Analysis of recent research and publications}

Currently, forecasting of electricity consumption in most of industrial enterprises is made on the experts' evaluation method, which in most of cases is not able to provide the necessary forecast accuracy. Electricity consumption forecasting gives us primary information for planning normal operating modes in energy management.

The accuracy of forecasting directly depends on the calculation methods. There are a large number of models and methods of short-term forecasting of the load on the power system of a metallurgical enterprise.

The formation and development of methods of mathematical modeling, forecasting and planning of electricity consumption, in particular in metallurgy, is related with the work of scientists, an overview of the main ideas of those are given below.

The monograph by Belt C.K. [5] is a fundamental work in energy management in the metallurgical industry.
The main idea that can be traced in it is that in the metallurgical industry there are unique processes and conditions those require a more individual approach. The author gives an explanation that the general methods of energy management in the very metallurgical industry, describes the advantages and reasons for implementing an energy management program, as well as reveal the basic indicators, tells us about data analysis, project identification and processes improvement.

In the article [6] a group of scientists presents a systematic review of existing publications on energy management in industry, that identifies five main elements of energy management, based on the following topics: strategy; planning, implementation; operation, control; organization and culture. The authors have developed a conceptual structure of energy management, which shows that a comprehensive approach is needed to effectively use the existing potential of energy efficiency.

The book [7] was written by the authors of the Neural Network Toolbox for MATLAB and provides a detailed description of the fundamental architectures of neural networks, learning rules, and applications for solving practical problems.

In [8], the authors offer the use of a deep neural network (DNN) for short-term electrical load prediction (STLF), which allowed to overcome the problems of nonlinearity and achieve higher prediction accuracy.

The manual [9] covers the latest trends and technologies in energy engineering and related industries, contains the latest materials on energy planning and policy.

The educational publication [10] explores a number of sustainable energy sources and tools used to analyze industry and future energy trends. The text contains an overview of energy economics with an integrated software package for research on energy use dynamics and forecasting; climatic and environmental factors of using energy are taken into consideration.

The main disadvantage of the existing methods is the need to build a load model and the constant refinement of the designed model. Another disadvantage of these methods is the inaccurate setup of the relationship between input and output variables, because the relationships between them are nonlinear.

Most of the existing power consumption forecasting algorithms are developed in the energy sector function as a combination of various statistical methods. However, due to the nonlinear relationship between the factors and the load on which it depends, qualitative modeling is a very complex process. The known methods of forecasting electricity consumption do not work with distorted or incomplete data, so we need new methods, approaches of forecasting electricity consumption, those could take into account different types of data.

In this paper, based on the analysis, the MATLAB complex with the Neural Network Toolbox was chosen to develop a model for forecasting the energy consumption of a metallurgical enterprise on the basis of ANN. 
Highlight of the earlier unresolved parts of the general problem. Aim of the study

When we are building a model of forecasting electricity consumption for a metallurgical enterprise, several tasks are being set. They are:

1. To construct a mathematical model by processing the data on the load for the past period of time;

2. To obtain a forecast based on the obtained model.

The task of this study is to get as much information as possible from the available data to do and to build the most accurate forecast possible. The specific actions are selected on the basis of available data and availability of informational and technical systems. The solvation of this problem requires preliminary research and descriptive analysis.

To solve the problem of forecasting electricity consumption, a number of smaller subtasks are set, those at the final stage will achieve the goal - to build a forecast with maximum accuracy.

The general task is divided into a number of subtasks, those include:

- descriptive analysis of the time series, or graphical analysis. The graphic analysis gives us an ability to identify obvious trends and patterns in the original data;

- time series research, as well as identification of regular and permanent components;

- obtaining an accurate forecast of the time series, taking into account fluctuations; forecast.

- evaluation of the quality of the constructed

The study of forecasting approaches shows that there is no standard, single method for forecasting electricity consumption: any enterprise has its special technological cycles, those together form a process that is unique to every enterprise.

The electricity consumption processes have functional, cyclical and random tendencies. The cyclic dependencies (they are usually daily, weekly and annual) are the easiest to predict. The cyclical trends, according to preliminary estimates, are for about $70-80 \%$ of all changes in the process of electricity consumption [11]. For example, the most significant cyclic factors in almost all industrial processes are the time, day of the week and the length of daylight.

The second of the important factors those are studied when solving the problem of forecasting are functional nature patterns (10 - 15\% of the total deviations) [12].This group can include deviations, those are explained by known and predicted factors those are specific to the metallurgical enterprise they are: air temperature or coolant use. Data analysis helps us to identify these factors and calculate their weight share in the energy consumption process.

The third component of the forecast is random trends. Their percentage share in the overall process is small, but the amplitude of deviations can be significant.

Operational forecast of electricity and power consumption is studied with the base on the current dynamics of power consumption at the last minute of each hour, but the main guideline for the technologist who forms the forecast of consumption for the planned period is the trajectory of power consumption, placed in shortterm consumption forecast. Therefore, providing the high accuracy of short-term forecast of electricity demand and capacity in power systems is a priority task. The operational forecasting of electricity and power consumption is a component of short-term forecasting.

The objective of this paper is to develop a model for forecasting the power system consumption of a metallurgical enterprise and its experimental testing on the data of "Dniprospetsstal" named after A. M. Kuzmin.

Solving the issue of improving the quality of operational consumption forecasting will be considered as a set of measures to improve the quality of short-term forecasting.

\section{Materials and methods}

The task of short-term forecasting of electricity consumption is a difficult task. The apparatus of artificial neural networks (ANN) has the ability to generalize information that describes nonlinear dependences in complex objects, processes and phenomena.

The shares of electricity consumption in the energy consumption system of PrJSC "Dniprospetsstal Electrometallurgical Plant" are determined by the production cycle, but in addition to the process of furnaces loading, they are affected by other needs those appear during the working hours. Therefore, as an array of input data for forecasting, statistical information was taken on the hourly consumption of electricity during the 24 hours period for the autumn months. Units of measurement of input information are MW / h.

Based on the training varieties and the formation of the forecast at the initial stage of the research, it is necessary for the ANN to select the weight coefficients in such a way that the standard deviation of the values of the outputs will be minimal. This requirement applies to the network of direct data extension and reverse error propagation (Feed-forward backpropagation - further FfB) [13]. Such network architecture requires its training at the expense of setting time targets, those should be the standard in the formation of the forecast and the input data that must be processed.

In order to set the input and target values of the function for the ANN model, it is necessary to use the architecture with nonlinear autoregression (NARX), which is presented in Figure 1. It is a recurring dynamic network with reversed connection that has several layers and is based on the autoregressive model:

$$
y(t)=f(y(t-1), y(t-2), \ldots, y(t-n), x(t-1), \ldots, x(t-n)) .
$$

The predicted value of $y(t)$ depends on the $n$ previous values of the output and on the $n$ previous values of the time series. Fig. 1 shows the neural network scheme used in this research.

The NARX network in figure 1 is a two-layer reversed expansion neural network. The sigmoidal function acts as a transfer function in the hidden layer, and the linear function acts as a transfer function in the output layer. 
The given network model uses delay lines with taps to store the previous values of $x(t)$ and $y(t)$. The original value of $y(t)$ is given back to the input of the network (after the delay), as $y(t)$ is a function dependent on the previous values: $y(t-1), y(t-2), \ldots, y(t-d)$.

There are two entrances in the network. One is external, and the other is connected to the output of the network, from that the input values are obtained. For each of the inputs there is a delay line with taps for storing the previous values. The number of neurons at the latent level will be established experimentally, and the number of delays is 2 .

A closed loop in nonlinear autoregression allows one-step predictions, that is, it predicts the value of $y(t)$ from the previous values of $x(t-1), x(t-2), y(t-1)$, and $y(t-2)$. A closed-loop circuit can be used to perform multistep prediction. This is caused by the fact that the predicted values of $y(t)$ will be used instead of the actual future values of $y(t)$.

Before you can start training a network that contains delay lines with taps, you must fill them with the initial values of input and output.

The task is to predict the time series, so as the input data will be used the numbers of time intervals in the prescribed manner, and as the output - the value of the analyzed energy consumption.

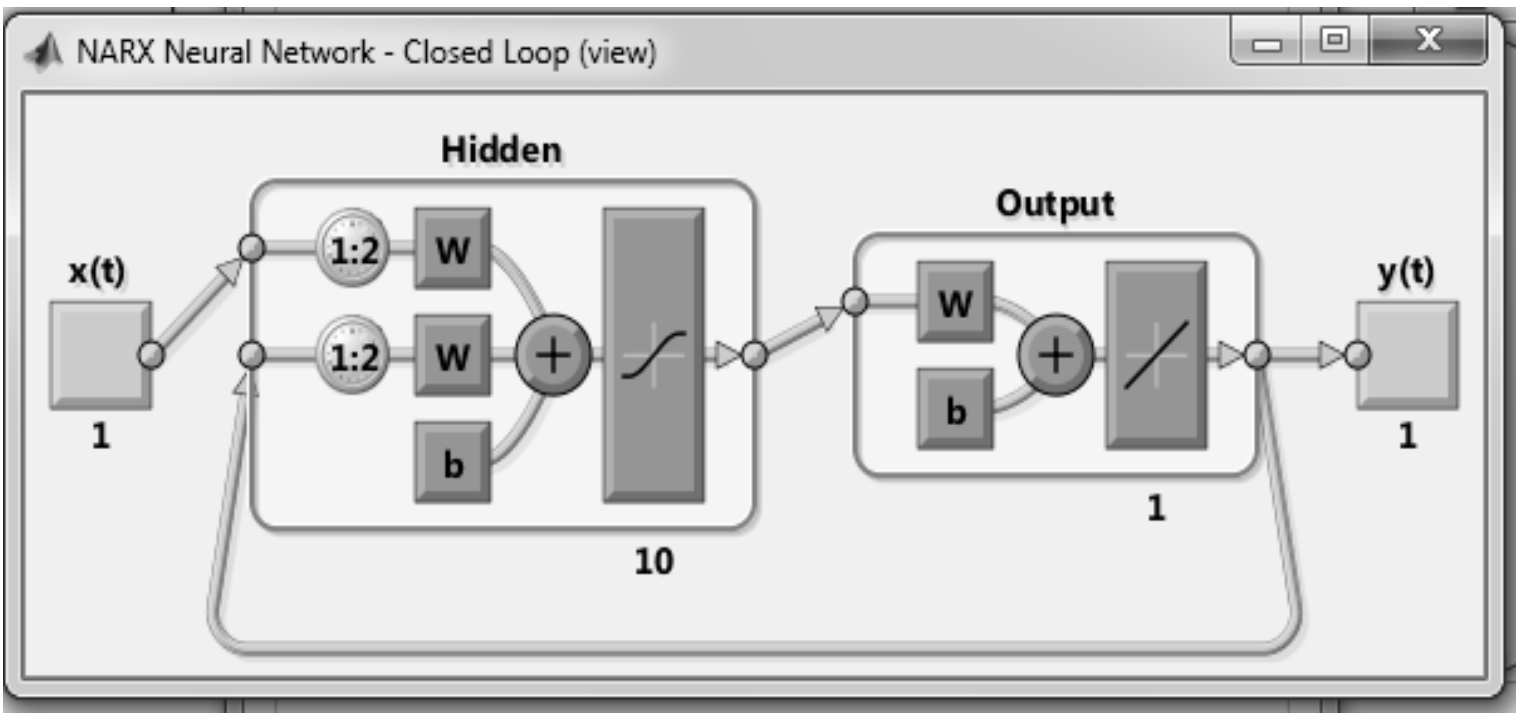

Fig. 1. Closed loop in a network of nonlinear autoregression

For effective network training, all input data is divided into three subsets. The first will be needed for training of a network (correction of scales). $70 \%$ of the data was used for the first one.

The second subset is necessary to avoid network overfitting. The control of network learning is carried out by calculating the error on the data from this subset. At the initial stage of learning the neural network, the error should be reduced. The over fitting will be evidenced by an increase in error. Therefore, a trained system will have scales, at those the error on the test subset would be minimal.

The third subset is a test. It is useful when comparing different models as an independent test of a trained network. Also, the test subset may indicate poor separation of the output data, if the minimum errors on the data and the verifiable subset are achieved in substantially distant ones from one iteration. For the second and third subsets, $15 \%$ of the data were allocated.
Another approach to forecasting energy consumption is deep learning [14]. A deep neural network allows you to process a large amount of input information in a short time, has the ability to build dependencies on noninformative input information, to detect hidden dependencies between the inputs and outputs.

Neural networks with long short-term memory (LSTM) have been created as a modification of recurrent neural networks (RNNs), those can be selected. Any recurrent neural network has the form of a chain of repeating modules of the neural network.

The core components of the LSTM network are the input sequence layer and the LSTM layer. The LSTM layer studies long-term relationships between time steps of given sequences.

The diagram in fig. 2 illustrates the architecture of a simple LSTM network for forecasting. The network is started from the input layer of the Sequence Input sequence, which provides the LSTM layer. To predict class marks, it ends with a Fully Connected layer and regression of the source layer.

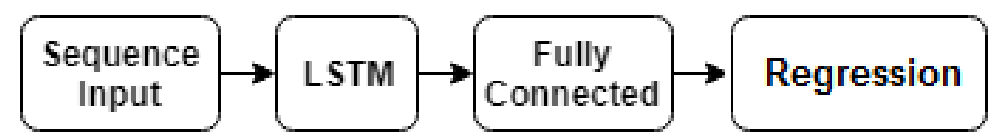

Fig. 2. Simple LSTM network architecture 
To predict the meaning of future sequence time steps, it is possible to train the LSTM chain from sequence to sequence, where the answers are training sequences with values shifted by one. Thus, at each time step of the input sequence, the LSTM network learns to predict the value of the next time step. The training of such a network is carried out using the method of adam adaptive moment estimation, optimization algorithm [14].

Forecast accuracy is estimated as the mean absolute error in percentages (MAPE):

$$
M A P E=\frac{1}{p} \sum_{i=1}^{p} \frac{\left|y_{i}-\bar{y}_{i}\right|}{y_{i}} \cdot 100,
$$

where $y_{i}-$ actual load values, forecast result, $p$ is the amount of data.

According to the analysis of publications [7, 13, 15], a forecast error of no more than $5 \%$ is acceptable.

\section{Study results and their discussion}

In the Neural Network Toolbox environment, it is possible to use the following algorithms for learning neural networks: nonlinear Levenberg-Marquardt optimization, Bayesian Regularization methods and conjugate gradient methods (Scaled Conjugate Gradient) those are detailed described in sources [7, 13]

For objectivity of comparison of indicators of quality of forecasting at application of various algorithms of forecasting with use of the corresponding architecture of construction of ANN one was chosen exactly and on the same day that gave an opportunity to compare the results of received forecasts in the most accurate way.

When modeling the process of electricity consumption in the power system at the initial stage, a network that has an architecture of direct data propagation and reverse error propagation (Feed-forward backpropagation, or $-\mathrm{FfB}$ ) and trained according to the Levenberg-Marquardt Algorithm was chosen.

The training results of the neural network in MATLAB are presented in the following way (fig. 3).

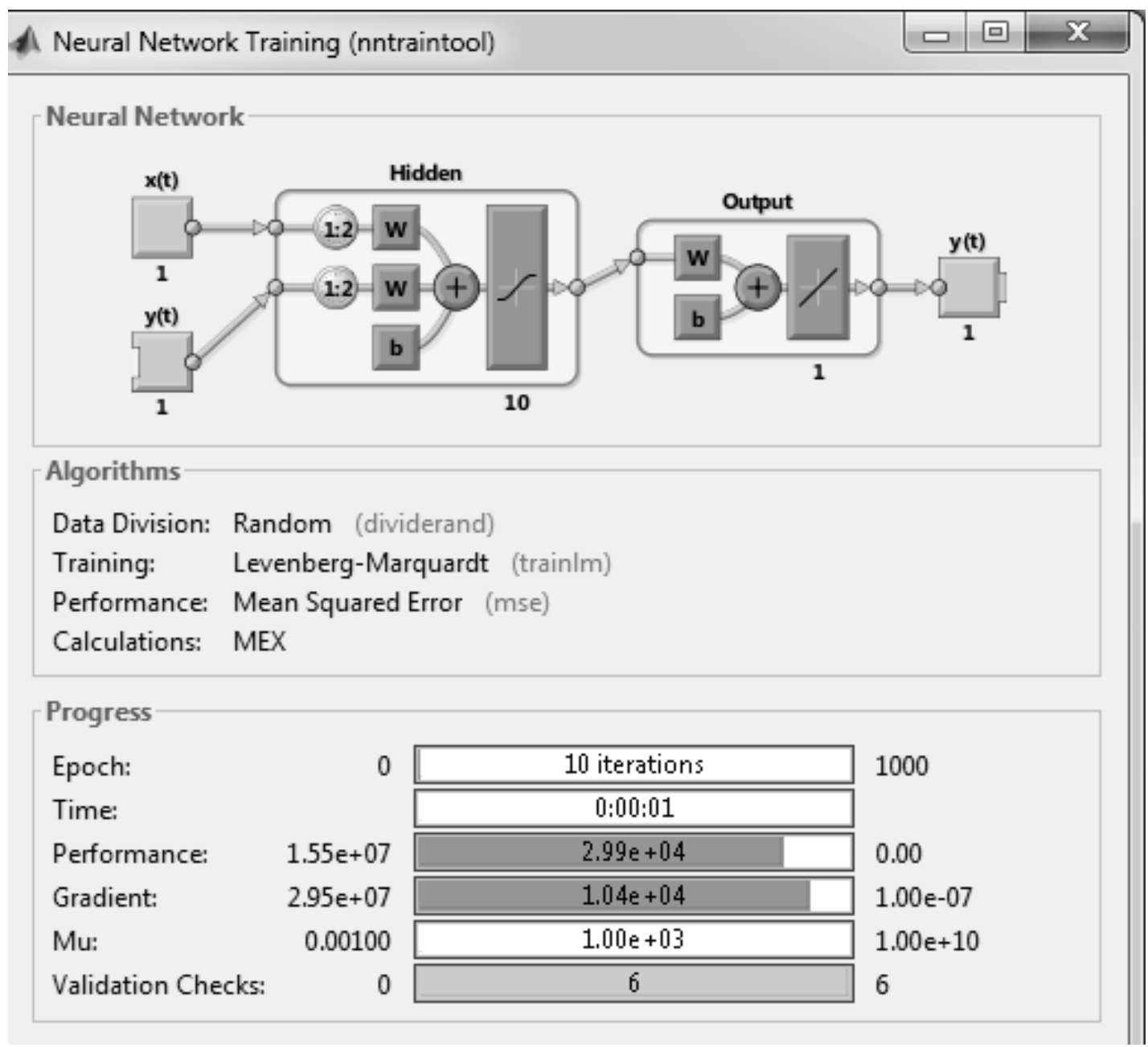

Fig. 3. The Neural network training results performed by Levenberg-Marquardt Algorithm on the architecture of the FfB model

In the following stages of the training, the same type of architecture, FfB, was used, but the learning algorithm changed: first, the Bayesian regularization algorithm, then the combined gradient method.
According to the obtained results, the comparison of the generated forecast from the actual values using different training algorithms on the FfB architecture are presented in fig. 4 . 


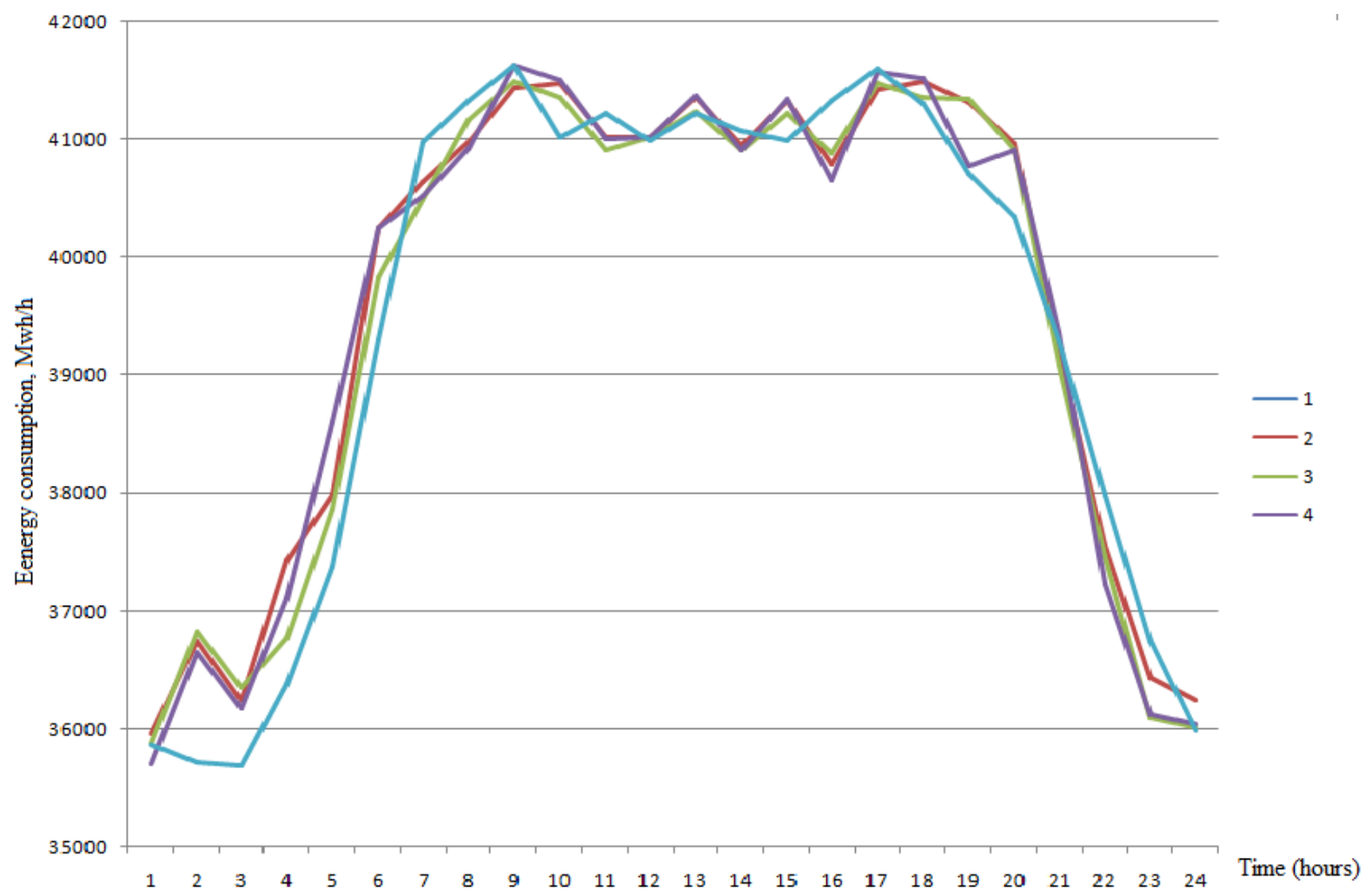

where 1 - The actual value of energy consumption; 2 - forecast value of energy consumption according to Levenberg-Marquardt Algorithm; 3 - forecast value of energy consumption according to Bayesian regularization algorithm; 4 - forecast value of energy consumption by the method of combined gradients

Fig. 4. Results of energy consumption forecasting using ANN

In contrast to the above ANN, a separate software solution is required for forecasting using the LSTM network.

The sequence of software implementation of deep training in the MATLAB package is:

1) to import data from Excel;

2) to divide the data into a training sample and a test;

3) to standardize the data to have a zero mean and modular deviation;

4) to create an LSTM regression network. Set the LSTM layer, which has 5 hidden modules. Further increase in the number of LSTM modules or layers doesn't improve the forecast quality due to insignificant quantity of training data in our case.

5) to set training options. Specify the 'adam' algorithm and train LSTM with the given training options using train Network for 250 epochs. To prevent the gradients from exploding, set the gradient threshold to 1;

6) to predict the value of several time steps in the future, use the predict And Update State function;

7) to initiate a network state, first predict the training data XTrain. Then we make the first prediction using the last time step of the learning answer YTrain (end).
The results of forecasting with the LSTM network are shown in fig. 5.

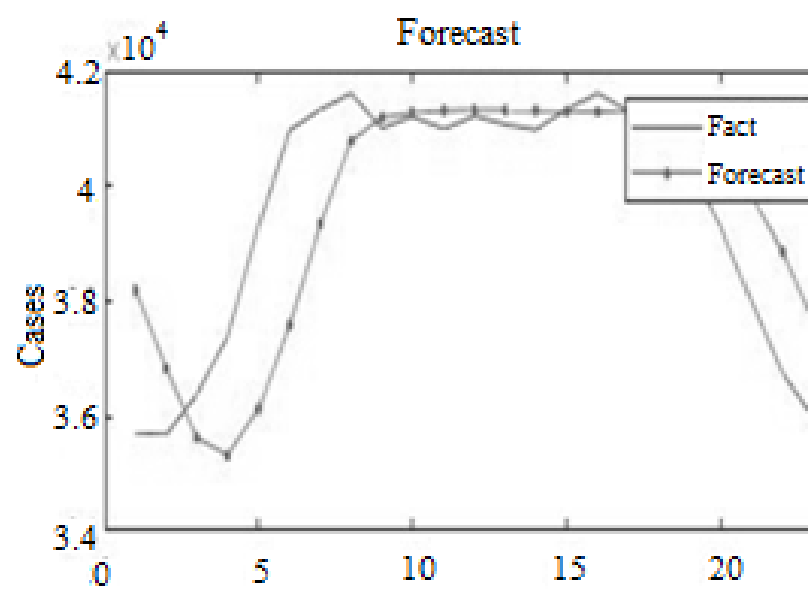

Fig. 5. Display of actual and forecasted data values with the LSTM network

The results of the obtained forecasts and calculations of forecasting accuracy according to formula (2) on different training algorithms are summarized in table 1.

Table 1. Characteristics of ANN training

\begin{tabular}{|c|c|c|c|c|}
\hline Parameters & $\begin{array}{c}\text { Levenberg - Marquardt } \\
\text { Algorithm }\end{array}$ & Bayesian regularization algorithm & Combined gradients & $\begin{array}{c}\text { LSTM } \\
\text { Network }\end{array}$ \\
\hline Epoches number & 10 & 211 & 7 & 250 \\
\hline Training time & $0: 00: 01$ & $0: 00: 05$ & $0: 00: 01$ & $0: 00: 05$ \\
\hline MAPE, $\%$ & 2,87 & 3,07 & 3,27 & 2,59 \\
\hline
\end{tabular}


According to table 1, the best among the used ANN for this training is the LSTM network, the maximum prediction error is $2.59 \%$ modulus per operating 24 hours period. In absolute terms, this is $1,069.76 \mathrm{MW}$.

The use of artificial neural networks allows to increase the consumption forecasting efficiency, as well as to consider the dynamic processes those are occurring in the power system, which affect the nature of electricity consumption and power, which increases the accuracy of forecasts.

To implement this task, the optimal software and hardware complex MATLAB was selected, that has tools for building and realizing ANN. We had the wide range of possibilities and proposed ready-made solutions so an analysis of the choice of the ANN architecture and the algorithm of its training was carried out in this software package.

Using MATLAB software package, experiments on the basis of statistical data of the metallurgical enterprise by the method of artificial neural networks were conducted. It is revealed that the developed neural networks may be used to make a forecast of electricity consumption for the 24 hours' time period ahead with a maximum accuracy of $2.87 \%$ of the actual volume of electricity consumed.

\section{Conclusion and perspectives of further development}

Developed models for forecasting energy consumption of "Electrometallurgical Plant "Dniprospetsstal" named after A. M. Kuzmin power systems based on LSTM ANN meet the requirements for the quality of short-term forecasting of consumption in power systems. But they fail to include all energy consumption problems and factors that affect the energy system of the enterprise. Therefore, there are a number of ways for the further model's improvement.

An important aspect of ferrous metallurgy enterprises is the risk of downtime for various reasons, the prediction of those using neural networks is considered in the article [16]. This fact makes a challenge for further research in this area regarding uninterrupted power supply and the impact of risk factors on the random component of the time series.

The issue is being analyzed in the articles by Chinese authors [17] relate to forecasting energy consumption in non-ferrous metallurgy, those enterprises have their own characteristics. The method of hybrid regression of reference vectors for research, that inspires to compare the results obtained with the help of neural networks of different architecture with the results obtained by other methods is used.

In the monograph Belt C.K. [5] shows a tendency to increase gas consumption in the winter months and emphasizes that reducing the energy used for the station heating may be a viable project. Therefore, the following studies we provide the possibility of introducing meteorological factors into the model of electricity consumption forecasting to increase the efficiency of ANN.

High accuracy of short-term hourly forecasting of electricity consumption is a necessary condition for normal operation in the wholesale market of electricity and capacity (WMEC), otherwise such market entry does not make sense. In such conditions, the financial position of the WMEC participant depends on the accuracy of forecasting, so there is a problem of estimation the economic efficiency of electricity consumption forecasting, but this requires additional research.

Management of a large electrometallurgical enterprise in terms of energy saving policy involves effective management of energy consumption by forecasting electricity consumption, that leads to new challenges and enhances the relevance of research in this area.

The forecasting results analysis done with the use of the developed models showed that the chosen approach with experimentally selected architectures and learning algorithms meets the necessary requirements that were set at the initial stage of creating a dynamic model of forecasting based on ANN. It can be concluded that the networks are built in the correct way, because the chosen learning algorithms make the model effective.

The practical value of the modeling carried out in this work is confirmed by a number of experiments performed on real and available for research data, those demonstrate the possibility of using the developed tool to solve forecasting problems.

The scientific novelty of this work is the formalization based on the neural network's theory of energy consumption forecasting models those include the daily volumes of electricity consumed.

The work was carried out as the part of the research work "Mathematical modeling of socio-economic processes and systems", the registration number DB05038, at the Department of System Analysis and Computational Mathematics of National University "Zaporizhzhya Polytechnic".

\section{References}

1. Kiyko, S. G. (2020), "Adaptive portfolio management of energy saving projects at a metallurgical enterprise", Innovative Technologies and Scientific Solutions for Industries, No. 4 (14), P. 56-70. DOI: https://doi.org/10.30837/ITSSI.2020.14.056

2. Hnatiienko, H. M., Snytiuk, V. Ie. (2008), Ekspertni tekhnolohii pryiniattia rishen, TOV "Maklaut", Kyiv.

3. Molokanova, V. M., Orliuk, O. P., Petrenko, V. O. (2020), "Formation of metallurgical enterprise sustainable development portfolio using the method of analyzing hierarchies", Naukovyi Visnyk Natsionalnoho Hirnychoho Universytetu, No. 2, P. 131-136. DOI: https://doi.org/10.33271/nvngu/2020-2/131

4. Kiyko, S. G. (2020), "Predictive adaptation in the management of the portfolio of energy saving projects at the metallurgical enterprise", Science and technology of the Air Force of the Armed Forces of Ukraine, No. 4 (41), P. 133-144. DOI: https://doi.org/10.30748/nitps.2020.41.16

5. Belt, C. K. (2017), Energy Management for the Metals Industry, CRC Press, New York. DOI: https://doi.org/10.1201/9781315156392 
6. Schulze, M., Nehler, H., Ottosson, M. (2016), "Energy management in industry: a systematic review of previous findings and an integrative conceptual framework", Journal of Cleaner Production, No. $112 \quad$ (5), P. 3692-3708. DOI: https://doi.org/10.1016/j.jclepro.2015.06.060

7. Hagan, M. T., Demuth, H. B., Beale, M. H. (2014), "Neural Network Design", available at : http://hagan.okstate.edu/NNDesign.pdf

8. Phyo, P. P., Jeenanunta, C. (2019), "Electricity load forecasting using a deep neural network", Engineering and Applied Science Research, No. 46 (1), P. 10-17, available at: https://ph01.tcithaijo.org/index.php/easr/article/view/116025 (last accessed 13 December 2020).

9. Goswami, D. Y., Kreith, F. (2015), Energy Efficiency and Renewable Energy Handbook, CRC Press, Boca Raton. DOI: https://doi.org/10.1201/b18947

10. Kutscher, Ch. F., Milford, J. B., Kreith, F. (2018), Principles of Sustainable Energy Systems, CRC Press, Boca Raton, DOI: https://doi.org/10.1201/b21404

11. Kirpichnikova, I. M., Saplin, L. A., Solomakho, K. L. (2014), "Prognozirovanie ob`emov potrebleniya elektroenergii", Vestnik YuUrGU. Energetika, No. 14 (2), P. 16-22, available at : https://dspace.susu.ru/xmlui/handle /0001.74/4942 (last accessed 13 December 2020).

12. Shumilova, G. P., Gotman, N. E., Starczeva, T. B. (2008), Prognozirovanie elektricheskikh nagruzok pri operativnom upravlenii elektroenergeticheskimi sistemami na osnove nejrosetevykh struktur, URO RAN, Ekaterinburg.

13. Bodyanskij, E. V., Rudenko, O. G. (2004), Iskusstvenny`e nejronny`e seti: arkhitektury, obuchenie, primeneniya, Teletekh, Khar`kov.

14. "Time Series Forecasting Using Deep Learning" ["Prognozirovaniye vremennykh ryadov Ispol'zuya glubokoye obucheniye "], available at : https://docs.exponenta.ru/deeplearning/ug/time-series-forecasting-using-deep-learning.html (last accessed 13 December 2020).

15. Brejdo, I. V., Bulatbaeva, Yu. F., Orazgaleeva, G. D. (2020), "Algoritm sozdaniya modeli kratkosrochnogo prognozirovaniya energopotrebleniya na osnove nejronnoj seti v Matlab", VI International Scientific Conference. Actual Problems of Technical Sciences, Krasnodar, April 2020, P. 1-6, available at : https://moluch.ru/conf/tech/archive/367/15614/ (last accessed 13 December 2020).

16. Vichuzhanin. V. V., Rudnichenko. N. D. (2016), "Development of the neural network model for prediction failure risk's of the complex technical systems components", Informatics and Mathematical Methods in Simulation, Vol. 6/ 4, P. 333-338.

17. Huang, Z., Yang, C., Zhou, X. et al (2020), "Energy Consumption Forecasting for the Nonferrous Metallurgy Industry Using Hybrid Support Vector Regression with an Adaptive State Transition Algorithm", Cognitive Computation, Vol. 12, P. 357-368. DOI: https://doi.org/10.1007/s12559-019-09644-0

\section{Відомості про авторів / Сведения об авторах / About the Authors}

Received 28.02.2021

Бакурова Анна Володимирівна - доктор економічних наук, професор, Національний університет "Запорізька політехніка", професор кафедри системного аналізу та обчислювальної математики, Запоріжжя, Україна; email: abaka111060@gmail.com; ORCID: http://orcid.org/0000-0001-6986-3769.

Бакурова Анна Владимировна - доктор экономических наук, профессор, Национальный университет "Запорожская политехника", профессор кафедры системного анализа и вычислительной математики, Запорожье, Украина.

Bakurova Anna - Doctor of Sciences (Economics), Professor, National University "Zaporizhzhia Polytechnic", Professor of the Department of Systems Analysis and Computational Mathematics, Zaporizhzhia, Ukraine.

Юськів Олеся Ігорівна - Національний університет "Запорізька політехніка", аспірант кафедри системного аналізу та обчислювальної математики, Запоріжжя, Україна; email: yuskivolesya@rambler.ru; ORCID: https://orcid.org/0000-0002-76697647.

Юськив Олеся Игоревна - Национальный университет "Запорожская политехника", аспирант кафедры системного анализа и вычислительной математики, Запорожье, Украина

Yuskiv Olesia - National University " Zaporizhzhia Polytechnic", Postgraduate of the Department of Systems Analysis and Computational Mathematics, Zaporizhzhia, Ukraine.

Широкорад Дмитро Вікторович - кандидат фізико-математичних наук, Національний університет "Запорізька політехніка", доцент кафедри системного аналізу та обчислювальної математики, Запоріжжя, Україна; email: hoveringphoenix@gmail.com; ORCID: https://orcid.org/0000-0002-2784-4081.

Широкорад Дмитрий Викторович - кандидат физико-математических наук, Национальный университет "Запорожская политехника", доцент кафедры системного анализа и вычислительной математики, Запорожье, Украина.

Shyrokorad Dima - PhD (Physical and Mathematical Sciences), National University "Zaporizhzhia Polytechnic", Associate Professor of the Department of Systems Analysis and Computational Mathematics, Zaporizhzhia, Ukraine.

Рябенко Антон Євгенійович - кандидат фізико-математичних наук, Національний університет "Запорізька політехніка", доцент кафедри системного аналізу та обчислювальної математики Запоріжжя, Україна; email: rjabenkoae@gmail.com; ORCID: http://orcid.org/0000-0001-7738-7918.

Рябенко Антон Евгеньевич - кандидат физико-математических наук, Национальный университет "Запорожская политехника", доцент кафедры системного анализа и вычислительной математики, Запорожье, Украина.

Riabenko Anton - PhD (Physical and Mathematical Sciences), National University "Zaporizhzhia Polytechnic", Associate Professor of the Department of Systems Analysis and Computational Mathematics, Zaporizhzhia, Ukraine.

Терещенко Еліна Валентинівна - кандидат фізико-математичних наук, доцент, Національний університет "Запорізька політехніка", доцент кафедри системного аналізу та обчислювальної математики, Запоріжжя, Україна; email: elina_vt@ukr.net, ORCID: http://orcid.org/0000-0001-6207-8071.

Терещенко Элина Валентиновна - кандидат физико-математических наук, доцент, Национальный университет "Запорожская политехника", доцент кафедры системного анализа и вычислительной математики, Запорожье, Украина.

Tereschenko Elina - PhD (Physical and Mathematical Sciences), Associate Professor, National University "Zaporizhzhia Polytechnic", Associate Professor of the Department of Systems Analysis and Computational Mathematics, Zaporizhzhia, Ukraine. 


\section{НЕЙРОМЕРЕЖЕВЕ ПРОГНОЗУВАННЯ ЕНЕРГОСПОЖИВАННЯ МЕТАЛУРГІЙНОГО ПІДПРИЕМСТВА}

Предметом дослідження $є$ методи побудови і навчання нейронних мереж як апарату нелінійного моделювання для розв'язання задачі прогнозування енергоспоживання металургійних підприємств. Метою даної роботи $\epsilon$ розробка моделі прогнозування споживання енергосистеми металургійного підприємства i його експериментальне випробування на доступних для дослідження даних ПрАТ "Дніпроспецсталь". Вирішені наступні завдання: аналіз часового ряду електроспоживання; побудова моделі, за допомогою якої обробляються дані про електроспоживання за історичний період; побудова якомога точнішого прогнозу фактичного обсягу електроенергії на добу вперед; оцінка якості прогнозу. Використано методи: аналізу часових рядів, нейромережевого моделювання, короткострокового прогнозування енергоспоживання в металургійній промисловості. Отримані результати: для розробки моделі прогнозування енергоспоживання металургійного підприємства на основі штучних нейронних мереж був обраний комплекс MATLAB 3 пакетом інструментів Neural Network Toolbox. При проведенні експериментів на основі доступних статистичних даних металургійного підприємства було виконано відбір архітектур і алгоритмів навчання нейронних мереж. Кращі результати показали мережа прямого поширення даних і зворотного поширення помилки, архітектура 3 нелінійною авторегресією $\mathrm{i}$ алгоритмами навчання: нелінійної оптимізації Levenberg-Marquard, метод Bayesian Regularization й метод сполучених градієнтів. Також розглянуто інший підхід - глибоке навчання, а саме нейронна мережа 3 довгою короткостроковою пам'яттю LSTM і алгоритмом навчання adam. Така глибока нейронна мережа дозволяє обробляти великі обсяги вхідної інформації за короткий час і будувати залежності за неінформативної вхідної інформації. Найбільш ефективною серед розглянутих нейронних мереж виявилася мережа LSTM, у якій показник максимальної помилки прогнозування мав мінімальне значення. Висновки: аналіз результатів прогнозування 3 використанням розроблених моделей показав, що обраний підхід з експериментально відібраними архітектурою і алгоритмами навчання задовольняє необхідним вимогам точності прогнозу при розробці моделі прогнозування на базі штучних нейронних мереж. Застосування моделей дозволить автоматизувати високоточне оперативне погодинне прогнозування енергоспоживання в ринкових умовах.

Ключові слова: енергоспоживання; прогнозування; штучна нейронна мережа; часовий ряд.

\section{НЕЙРОСЕТЕВОЕ ПРОГНОЗИРОВАНИЕ ЭНЕРГОПОТРЕБЛЕНИЯ МЕТАЛЛУРГИЧЕСКОГО ПРЕДПРИЯТИЯ}

Предметом исследования являются методы построения и обучения нейронных сетей как аппарата нелинейного моделирования для решения задачи прогнозирования энергопотребления металлургических предприятий. Целью данной работы является разработка модели прогнозирования потребления энергосистемы металлургического предприятия и его экспериментальное испытание на доступных для исследования данных ЧАО "Днепроспецсталь". Решены следующие задачи: анализ временного ряда электропотребления; построение модели, с помощью которой обрабатываются данные об электропотреблении за исторический период; построение как можно более точного прогноза фактического объема электроэнергии на сутки вперед; оценка качества прогноза. Использованы методы: анализа временных рядов, нейросетевого моделирования, краткосрочного прогнозирования энергопотребления в металлургической промышленности. Полученные результаты: для разработки модели прогнозирования энергопотребления металлургического предприятия на основе искусственных нейронных сетей был выбран комплекс MATLAB с пакетом инструментов Neural Network Toolbox. При проведении экспериментов на основе доступных статистических данных металлургического предприятия был выполнен отбор архитектур и алгоритмов обучения нейронных сетей. Лучшие результаты показали сеть прямого распространения данных и обратного распространения ошибки, архитектура с нелинейной авторегрессией и алгоритмами обучения: нелинейной оптимизации Levenberg-Marquard, метод Bayesian Regularization и метод сопряженных градиентов. Также рассмотрен другой подход - глубокое обучение, а именно нейронная сеть с длинной краткосрочной памятью LSTM и алгоритмом обучения adam. Такая глубокая нейронная сеть позволяет обрабатывать большие объемы входной информации за малое время и строить зависимости при неинформативной входной информации. Наиболее эффективной среди рассмотренных нейронных сетей оказалась сеть LSTM, у которой показатель максимальной ошибки прогнозирования имел минимальное значение. Выводы: анализ результатов прогнозирования с использованием разработанных моделей показал, что выбранный подход с экспериментально отобранными архитектурами и алгоритмами обучения удовлетворяет необходимым требованиям точности прогноза при разработке модели прогнозирования на базе искусственных нейронных сетей. Применение моделей позволит автоматизировать высокоточное оперативное почасовое прогнозирование энергопотребления в рыночных условиях.

Ключевые слова: энергопотребление; прогнозирование; искусственная нейронная сеть; временной ряд.

Бібліографічні описи / Bibliographic descriptions

Бакурова А. В., Юськів О. І., Широкорад Д. В., Рябенко А. Є., Терещенко Е. В. Нейромережеве прогнозування енергоспоживання металургійного підприємства. Сучасний стан наукових досліджень та технологій в промисловості. 2021. № 1 (15). C. 14-22. DOI: https://doi.org/10.30837/ITSSI.2021.15.014

Bakurova, A., Yuskiv, O., Shyrokorad, D., Riabenko, A., Tereschenko, E. (2021), "Neural network forecasting of energy consumption of a metallurgical enterprise", Innovative Technologies and Scientific Solutions for Industries, No. 1 (15), P. 14-22. DOI: https://doi.org/10.30837/ITSSI.2021.15.014 